\title{
Peningkatan Kinerja Unit Filtrasi di Instalasi Pengolahan Air Minum Unit Sewon-Bantul dengan Penggantian Sistem Backwash Ditinjau dari Parameter Besi (Fe) dan Mangan (Mn)
}

\author{
Delvira Jayatri Prasasti, Andik Yulianto, dan Luqman Hakim \\ Program Studi Teknik Lingkungan, Fakultas Teknik Sipil dan Perencanaan \\ Universitas Islam Indonesia \\ email: andik_y@ftsp.uii.ac.id
}

\begin{abstract}
Abstrak
Instalasi Pengolahan Air Minum (IPAM) Unit Sewon-Bantul memiliki kapasitas produksi 10 L/det. Permasalahan pada IPAM unit Sewon adalah tingginya kadar mangan (Mn) dalam air baku, bahkan setelah melalui pengolahan hingga didistribusikan ke masyarakat kadar mangan juga masih tinggi. Pada unit filtrasi khususnya, sistem backwash yang digunakan selama ini adalah menggunakan air yang mengandung klorin sehingga dapat mempengaruhi kinerja mikroorganisme. Untuk itulah diperlukan peningkatan kinerja unit pengolahan air bersih pada IPAM unit Sewon agar dihasilkan air bersih yang sesuai dengan standar kesehatan. Metode penelitian yang digunakan adalah pemeriksaan langsung di lapangan dan pengujian yang dilakukan di laboratorium. Pengambilan sampel dilakukan pada lima titik yaitu inlet filter, tiga outlet filter, dan air yang siap didistibusikan. Pada penelitian dilakukan trial dengan mengganti sistem backwash pada salah satu dari tiga unit filtrasi yaitu dengan menggunakan air baku dan memanfaatkan prinsip kinerja mikroorganisme. Dari hasil penelitian menunjukkan bahwa secara umum ketiga unit filter memiliki performance yang sama dalam removal besi (Fe) dan mangan (Mn). Penggantian sistem backwash yang dilakukan tidak memberikan hasil yang lebih baik dibandingkan kinerja kedua unit filter. Operasional dan pemeliharaan unit filter merupakan faktor penting yang menentukan keberhasilan trial yang dilakukan. Selain itu faktor lain yaitu kondisi lingkungan dan media filter yang digunakan juga berpengaruh terhadap kinerja filter. Secara umum kadar besi pada filter telah memenuhi baku mutu sedangkan kadar mangan masih di atas baku mutu yang ditetapkan.
\end{abstract}

Kata kunci: Filtrasi, Besi (Fe), Mangan (Mn), Backwash

\section{Pendahuluan}

Sebagian besar Instalasi Pengolahan Air Minum (IPAM) di Propinsi D.I Yogyakarta menggunakan air tanah sebagai air baku. Salah satu IPAM yang menggunakan air tanah sebagai air baku adalah IPAM Unit Sewon yang berada di wilayah kerja PDAM Bantul. IPAM unit Sewon memiliki kapasitas produksi 10 L/det dengan jumlah pelanggan aktif sebanyak 1104 unit.

Permasalahan yang terdapat pada IPAM unit Sewon adalah tingginya kadar mangan (Mn) dalam air baku dan bahkan setelah melalui pengolahan hingga pendistribusian kadar mangan juga masih cukup tinggi. Untuk kadar besi pada air baku $0.423 \mathrm{mg} / \mathrm{l}$ dan kadar mangan $3.02 \mathrm{mg} / \mathrm{l}$. Setelah melalui treatment, kadar besi menjadi 0.058 mg/l sedangkan kadar mangan menjadi $2.8 \mathrm{mg} / \mathrm{l}$. Hal ini menunjukkan efisiensi pengolahan untuk menurunkan kadar mangan masih sangat rendah yaitu hanya sebesar 7\%. Efisiensi pengolahan yang masih rendah mengindikasikan bahwa unit pengolahan air yang terdapat pada IPAM unit Sewon belum bekerja secara optimal. Pada unit 
filtrasi khususnya, sistem backwash yang digunakan selama ini adalah menggunakan air yang mengandung klorin. Hal ini berdampak pada kinerja mikroorganisme yang terdapat pada unit filter tersebut. Untuk itulah diperlukan peningkatan kinerja unit pengolahan air bersih pada IPAM unit Sewon agar dapat diketahui penyebab permasalahan dan menemukan solusi untuk lebih mengoptimalkan sistem pengolahan air di IPAM unit Sewon ini.

\section{Penggantian Sistem Backwash}

Penggantian sistem backwash dilakukan pada salah satu unit filtrasi yaitu pada filter I. Penggantian sistem backwash ini bertujuan untuk mengoptimalkan kinerja mikroorganisme pada media filter. Jika menggunakan air yang mengandung klorin dikhawatirkan dapat mengganggu kinerja bakteri dan bahkan dapat membunuh bakteri tersebut sehingga filter tidak dapat bekerja secara optimal. Bakteri yang berperan dalam mengoksidasi Fe2+ menjadi Fe3+ antara lain Gallionella, Crenothrix, Sphaerotilus- Lepothrix. Proses ini akan optimum pada pH 6-8. Bakteri memperoleh energi yang berasal dari proses oksidasi, seperti pada reaksi berikut:

$4 \mathrm{Fe} 2++\mathrm{O} 2+10 \mathrm{H} 2 \mathrm{O}=4 \mathrm{Fe}(\mathrm{OH}) 3+8 \mathrm{H}++$ Qcal.

Sedangkan bakteri yang berperan dalam removal Fe dan Mn antara lain Lepothrix, Crenothrix, Siderocapsa, Mettallogenium Pseudomonas. Jenis-jenis bakteri dalam removal Fe dan Mn ini merupakan bakteri berbentuk filament dan merupakan jenis bakteri yang melekat (attached bacteria) baik permanen maupun tidak permanen (Buchanan, 1916). Proses ini akan optimum pada $\mathrm{pH}>7.5$ dan kandungan oksigen terlarut $>5 \mathrm{mg} / \mathrm{l}$.

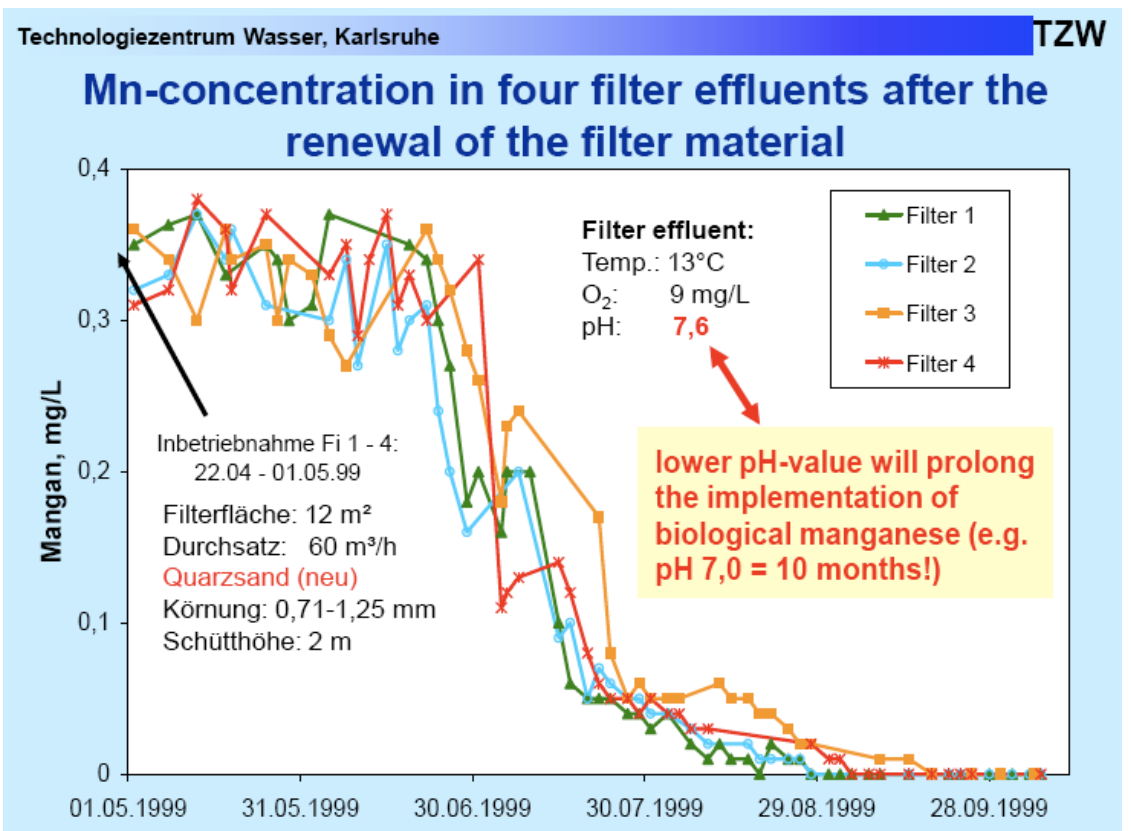

Gambar 1. Grafik Penerapan Biological Removal Mangan (Mn) oleh TZW Jerman (TZW, 1999) 
Perbaikan kinerja Filter dengan perubahan metode backwash dengan baik telah dilakuakn oleh TZW. Penerapan removal mangan secara biologi yang dilakukan oleh TZW Jerman pada Gambar 1, dapat dilihat bahwa untuk mendapatkan hasil yang optimal diperlukan konsentrasi oksigen terlarut yang tinggi dan $\mathrm{pH}$ sangat berpengaruh pada proses biologi ini. Pada $\mathrm{pH} 7.6$ kadar mangan dapat menurun hingga konsentrasi terendah dalam waktu 5 bulan. Namun jika pH hanya 7.0 akan membutuhkan waktu yang lama yaitu mencapai 10 bulan.

\section{Mekanisme Pengolahan Air menggunakan Mikroorganisme}

Pada pengolahan air yang memanfaatkan kinerja mikroorganisme ditandai dengan terbentuknya lapisan biofilm pada permukaan media filter. Biofilm terdiri dari sel-sel mikroorganisme yang melekat erat pada suatu permukaan sehingga berada dalam keadaan diam dan tidak mudah terlepas (irreversible). Pembentukan lapisan biofilm membutuhkan periode satu hingga tiga minggu. Periode ini memungkinkan pertumbuhan yang cukup dari lapisan biologis dalam lapisan pasir. Media pada filter membutuhkan pembersihan periodik. Lapisan biofilm pada filtrasi pasir lambat biasanya dibersihkan setiap satu hingga tiga bulan tergantung pada tingkat kekeruhan. Namun selama kekeruhan tinggi, pasir membutuhkan pembersihan setiap 2 minggu atau lebih sering. Selain kekeruhan, frekuensi pembersihan tergantung pada distribusi partikel, kualitas air yang masuk, dan temperatur air.

\section{Metode Penelitian}

Secara umum penelitian yang dilakukan adalah penelitian lapangan dengan melakukan trial pada salah satu unit filter. Trial dilakukan dengan mengganti sistem backwash pada salah satu dari tiga unit filtrasi. Dengan trial ini, air untuk backwash diganti dengan menggunakan air yang berasal dari aerasi (tanpa klorin) dengan tujuan agar mikroorganisme yang terdapat pada media.

Pengambilan sampel dilakukan pada 5 titik yaitu: 1 sampel air sebelum filtrasi, 3 sampel air setelah filtrasi, dan 1 sampel untuk air yang telah siap didistribusikan. Pemeriksaan kualitas air dilakukan secara in situ (di lapangan) dan di laboratorium. Pemeriksaan di lapangan meliputi pengukuran suhu, pH, oksigen terlarut dilakukan bersamaan dengan pengambilan sampel. Pemeriksaan di laboratorium meliputi parameter Fe dan Mn, dilakukan di Laboratorium Kualitas Air, Jurusan Teknik Lingkungan FTSP UII dengan prosedur uji SNI 06-6989.4-2004 untuk Fe dan dan SNI 066989.5-2004 untuk Mn. Untuk mengetahui efisiensi pengolahan maka dilakukan analisis data dari hasil uji laboratorium. Pada unit filtrasi ini dilakukan dengan membandingkan antara kualitas influent filter dan effluent filter. Diagram alir penelitian disajikan pada Gambar 2, sedangkan lokasi pengambilan sampel ditunjukkan pada Gambar 3. 


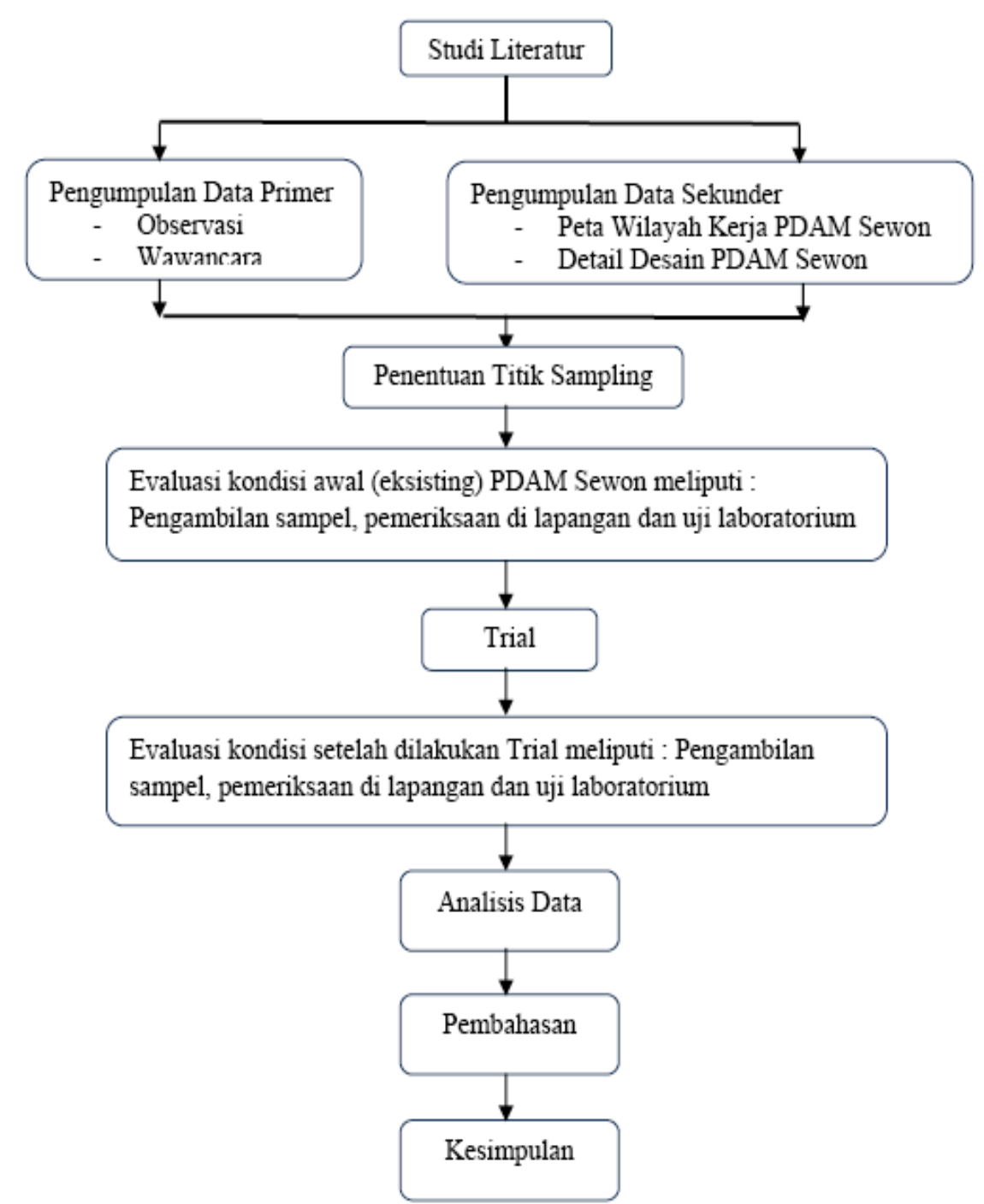

Gambar 2. Diagram Alir Metode Penelitian

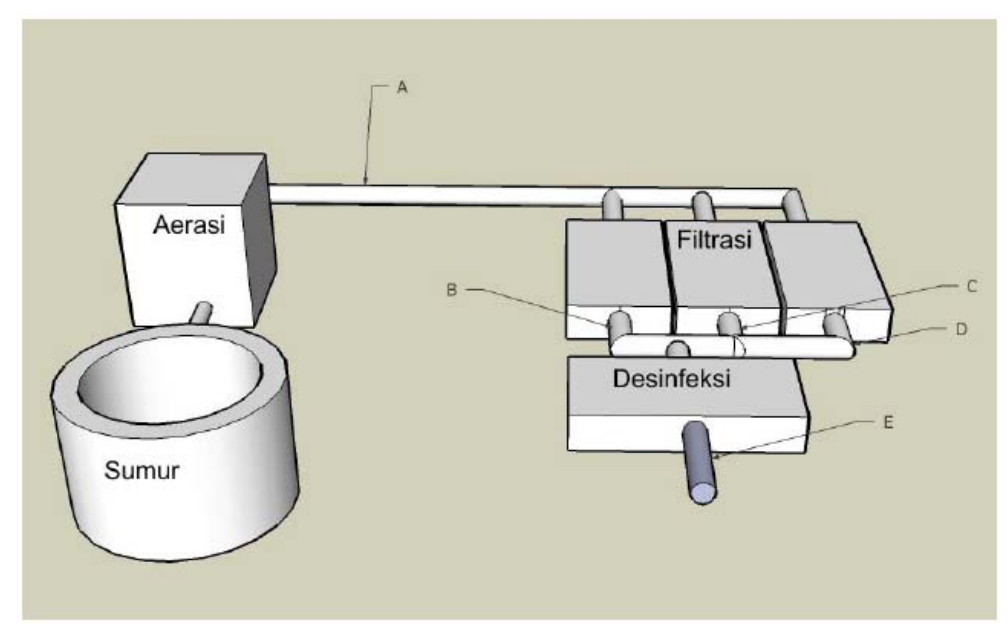

Gambar 3. Titik Pengambilan Sampel

\section{Hasil dan Pembahasan}

\section{Kondisi Eksisting}

Untuk karakteristik air baku dapat dilihat pada Tabel 1. 
Tabel 1. Karakteristik Air Baku

\begin{tabular}{|c|c|c|}
\hline Parameter & Nilai & Baku Mutu (Kepmenkes No. 907 Tahun 2002) \\
\hline Temperatur $\left({ }^{\circ} \mathrm{C}\right)$ & 28.9 & \\
\hline $\mathrm{pH}$ & 6.78 & $6.5-8.5$ \\
\hline Dissolved Oxygen (mg/l) & 1.73 & \\
\hline Kekeruhan (NTU) & 1.04 & 5 \\
\hline $\mathrm{Fe}(\mathrm{mg} / \mathrm{l})$ & 0.423 & 0.3 \\
\hline $\mathrm{Mn}(\mathrm{mg} / \mathrm{l})$ & 3.11 & 0.1 \\
\hline
\end{tabular}

Sumber: Data Primer, 2008

Berdasarkan data karakteristik air baku PDAM Bantul unit Sewon dapat diketahui bahwa parameter kimia yaitu besi (Fe) dan mangan (Mn) memiliki konsentrasi yang melebihi baku mutu.

\section{Kajian Media Filter}

Keseragaman media filter akan menentukan performance filter. Untuk mengetahui keseragaman media filter maka dilakukan sieve analysis sehingga terbentuk suatu lengkung ayakan. Lengkung ayakan setiap filter dapat dilihat pada Gambar 4.

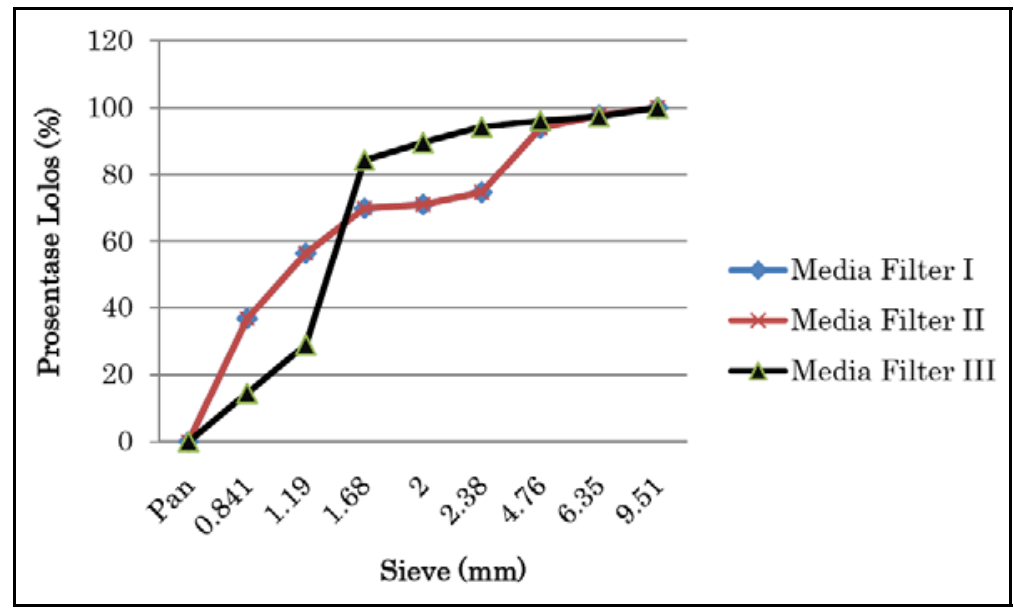

Gambar 4. Analisis Lengkung ayakan

Berdasarkan Gambar 4 dapat dilihat bahwa filter I dan II memiliki media yang tidak seragam. Sejumlah pasir memiliki ukuran yang berlainan. Sedangkan filter III masih memiliki media yang seragam yaitu antara sieve $1.19 \mathrm{~mm}$ dan $1.68 \mathrm{~mm}$. Untuk ukuran butiran media baik pada filter I, filter II, maupun filter III masih terdapat ukuran butiran yang tidak sesuai dengan kriteria yaitu butiran pasir lebih besar dari $3 \mathrm{~mm}$.

Jika dilihat dari segi teknik akan lebih baik jika mengutamakan lapisan pasir dengan keseragaman sedapat mungkin. Dengan kata lain, ukuran dari butir-butir pasir sebanyak mungkin sama besar. Jika pasir kurang seragam atau banyak butiran pasir dengan ukuran berlainan, maka daya hambat pada lapisan pasir akan lebih besar. Selain itu pada butir-butir kecil, pada saat ekspansi pembilasan 
balik akan terbawa ke lapisan bagian atas dimana filter akan cepat tersumbat. Hal ini menyebabkan jangka waktu pemakaian yang lebih pendek dan mengakibatkan pelekatan lumpur juga kurang pada pasir saringan. (OASEO, 2007).

\section{Analisa pH, Oksigen Terlarut, dan Temperatur pada Unit Filter}

Kondisi pH, oksigen terlarut, dan suhu pada saat pengambilan sampel dapat dilihat pada Gambar 5, 6, dan 7.

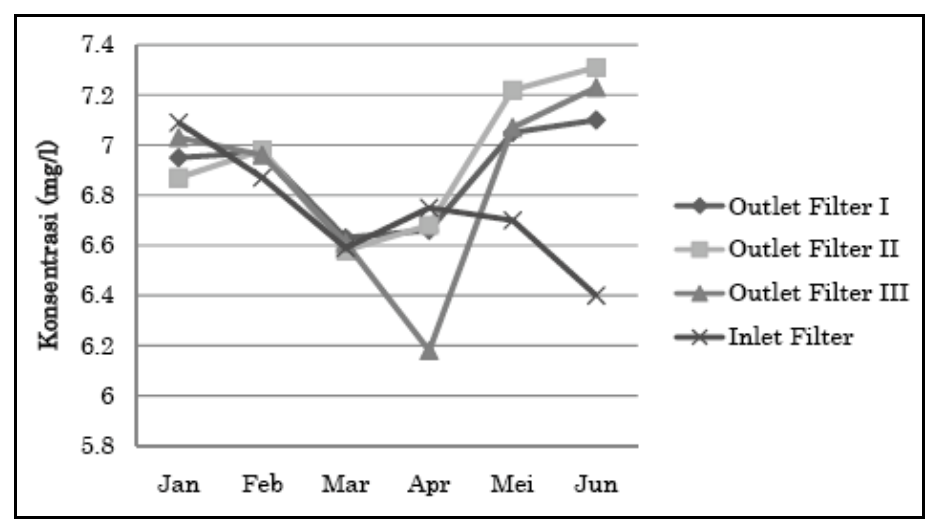

Gambar 5. Grafik Hasil Pengukuran Parameter $\mathrm{pH}$

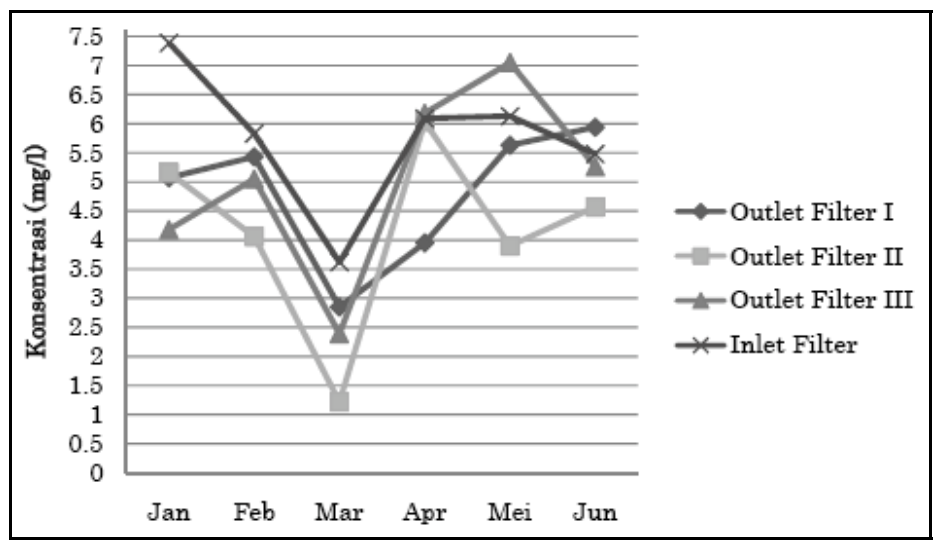

Gambar 6. Grafik Hasil Pengukuran Parameter DO

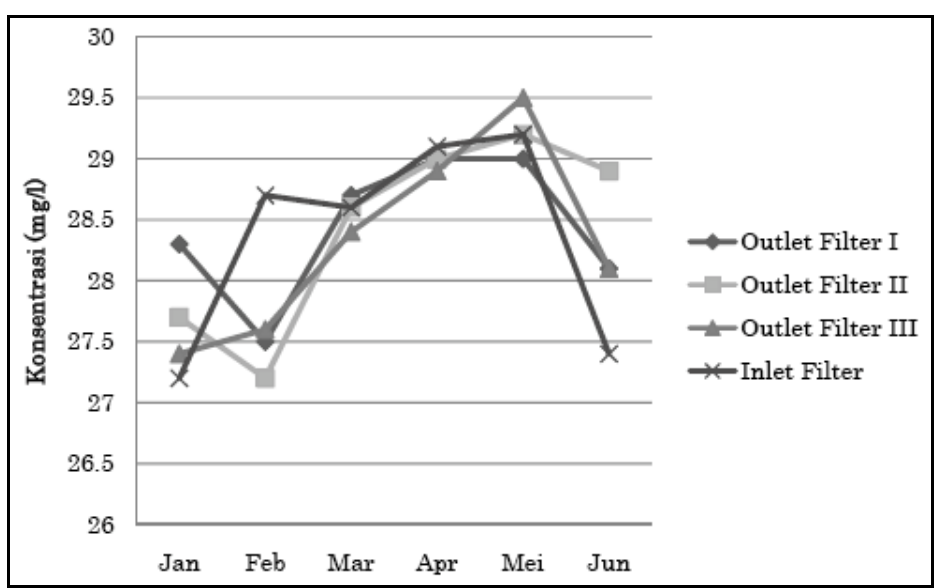

Gambar 7. Grafik Hasil Pengukuran Parameter Suhu 
Secara umum pH pada air baku adalah 6-8.5 (Webber and Stumm, 1963). Untuk oksidasi besi, pH yang dibutuhkan lebih besar dari 7.5 dan untuk oksidasi mangan $\mathrm{pH}$ yang dibutuhkan lebih besar dari 9.5. Pada studi-studi tertentu, efisiensi unit filtrasi sangat peka terhadap perubahan pH. Jika dilihat dari kondisi $\mathrm{pH}$ pada filter yang hanya berkisar antara 6-7.2 maka kondisi $\mathrm{pH}$ ini kurang optimal untuk mengoksidasi besi dan mangan.

Parameter $\mathrm{pH}$ dan konsentrasi oksigen terlarut dalam air cenderung menurun setelah melalui filter. Kandungan oksigen terlarut pada ketiga unit filter berkisar antara 1.22-7.39 mg/l. Untuk menerapkan pengolahan secara biologis kandungan oksigen terlarut yang dibutuhkan adalah lebih dari $4 \mathrm{mg} / \mathrm{l}$.

Penurunan konsentrasi oksigen terlarut umumnya akibat aktivitas biologi maupun faktor fisik (Boynton and Kemp, 2000). Salah satunya disebabkan aktivitas mikroorganisme dalam air. Mikroorganisme melakukan proses metabolisme dan oksidasi dengan menggunakan oksigen yang terlarut dalam air. Mikroorganisme memperoleh energi yang berasal dari proses oksidasi, seperti pada reaksi berikut:

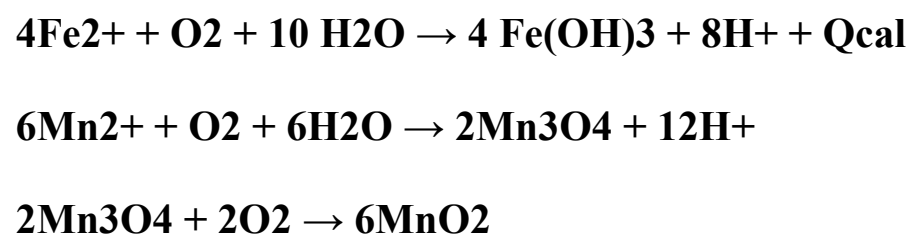

Reaksi di atas menunjukkan bahwa aktivitas mikroorganisme membutuhkan oksigen terlarut dalam air dan menyebabkan kadar oksigen terlarut menurun setelah melalui filter. Kelarutan oksigen di dalam air dipengaruhi oleh nilai dari Konstanta Henry dimana nilai Konstanta Henry akan semakin tinggi pada suhu yang semakin rendah, sehingga semakin tinggi suhu air maka akan semakin rendah kelarutan oksigen di dalamnya. Nilai oksigen terlarut berkisar antara $14,6 \mathrm{mg} / \mathrm{l}$ pada suhu $0^{\circ} \mathrm{C}$ sampai dengan $7,6 \mathrm{mg} / \mathrm{l}$ pada suhu $30^{\circ} \mathrm{C}$. Pada suhu yang semakin tinggi nilai $\mathrm{pH}$ juga cenderung menurun. Setiap kenaikan suhu $25^{\circ} \mathrm{C}$, pH air akan menurun sekitar 0.45. (Sawyer, 2003).

\section{Penurunan Kadar Besi (Fe) pada Ketiga Unit Filter}

Fluktuasi konsentrasi besi (Fe) dapat dilihat pada Gambar 8. Berdasarkan grafik pada Gambar 8 dapat dilihat bahwa secara umum, kinerja ketiga unit filter tidak mengalami perbedaan yang signifikan dalam menurunkan kadar besi. Pada bulan pertama hingga bulan ketiga terjadi penurunan kadar Fe pada ketiga unit filter. Namun pada bulan keempat dan kelima kadar Fe meningkat dan 
bulan keenam mengalami penurunan kembali. Jika dibandingkan antara filter I (backwash tanpa klorin) dan kedua filter lainnya dapat dikatakan bahwa kinerja filter I tidak jauh lebih baik dibanding kedua filter lainnya. Hal ini dapat dilihat pada kadar Fe pada filter I yang lebih tinggi dibanding filter III pada bulan Januari, Maret, April, Mei, dan Juni.

Hasil penurunan kadar besi yang tidak jauh beda pada ketiga unit filter disebabkan karena ketiga unit filter menggunakan prinsip pengolahan yang sama. Walaupun salah satu filter menerapkan sistem backwash yang berbeda, namun faktor-faktor dan parameter lapangan tidak mendukung untuk keefektifan sistem tersebut. Hal ini dapat dilihat dari hasil pengujian setiap bulannya yang menunjukkan fluktuasi yang tinggi. Kadar Fe pada unit filter telah memenuhi Baku Mutu Kepmenkes No. 907 Tahun 2002, kecuali pada pengukuran bulan april dan mei yang melebihi 0.3 mg/l. Kadar Fe yang tinggi pada bulan april disebabkan karena $\mathrm{pH}$ yang rendah pada filter.

\section{Penurunan Kadar Mangan (Mn) pada Ketiga Unit Filter}

Fluktuasi konsentrasi mangan (Mn) dapat dilihat pada Gambar 9.

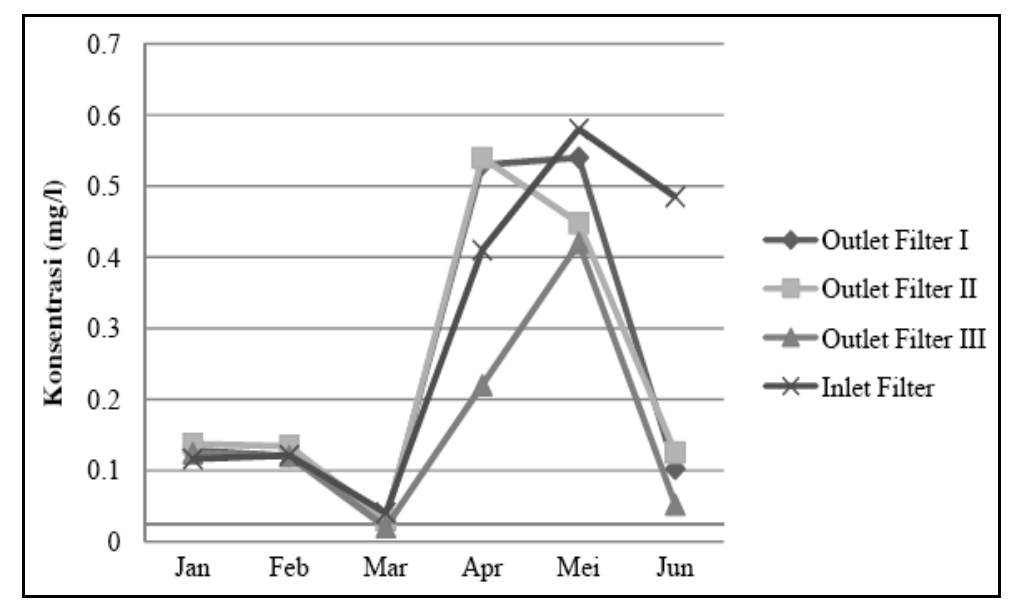

Gambar 8. Grafik Fluktuasi Kadar Fe pada Ketiga Unit Filter

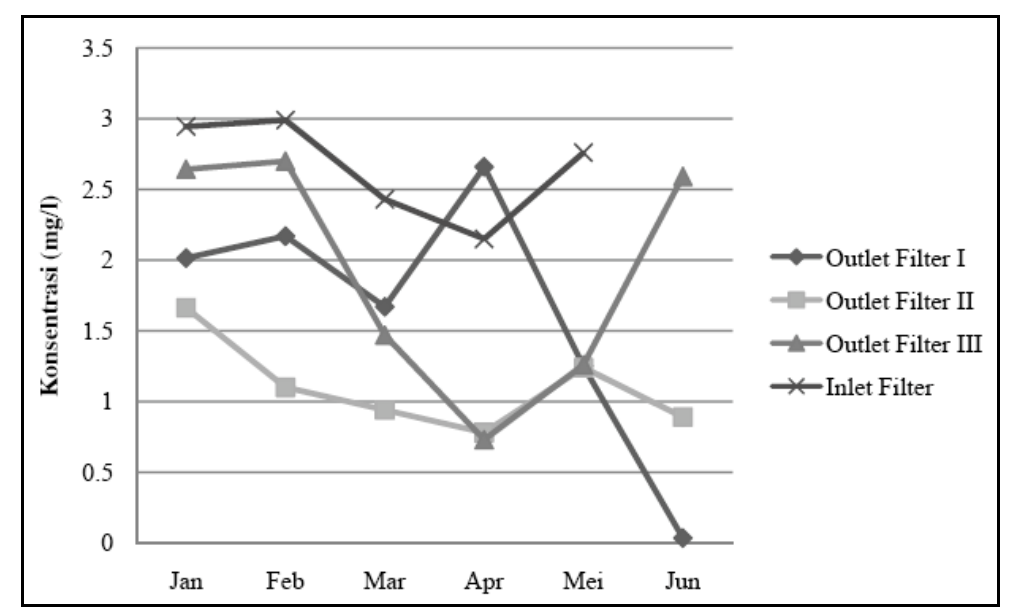

Gambar 9. Grafik Fluktuasi Kadar Mn pada Ketiga Unit Filter 
Untuk penurunan kadar mangan, pada filter pasir cepat, laju oksidasi dengan oksigen akan efektif jika $\mathrm{pH}>$ 7. Laju oksidasi Mn2+ lebih lambat daripada oksidasi Fe2+. Sedangkan oksidasi dengan menggunakan bakteri (Lepothrix, Crenothrix, Siderocapsa, Mettallogenium Pseudomonas) akan optimum jika $\mathrm{pH}>7.5$ dan kadar oksigen terlarut $>5.0 \mathrm{mg} / \mathrm{l}$. Secara umum kadar mangan pada unit filter masih di atas baku mutu Kepmenkes No. 907 Tahun 2002 yang mempersyaratkan kadar mangan tidak lebih dari $0.1 \mathrm{mg} / \mathrm{l}$. Bila dibandingkan dengan penerapan removal mangan secara biologi yang dilakukan oleh TZW Jerman, maka dapat dilihat bahwa untuk mendapatkan hasil yang optimal diperlukan konsentrasi oksigen terlarut yang tinggi dan $\mathrm{pH}$ sangat berpengaruh pada proses biologi ini. Pada pH 7.6 kadar mangan dapat menurun hingga konsentrasi terendah dalam waktu 5 bulan. Namun jika pH hanya 7.0 akan membutuhkan waktu yang lama yaitu mencapai 10 bulan. Kandungan oksigen terlarut dalam air juga mempengaruhi removal mangan. Dari grafik dapat dilihat bahwa biological removal mangan akan efektif pada DO hingga mencapai 9 mg/l. Namun untuk mencapai kondisi DO yang tinggi pada filter PDAM unit Sewon akan cukup sulit, hal ini bila dikaitkan dengan kondisi temperatur di Indonesia yang merupakan iklim tropis sementara temperatur di Jerman dapat berada pada titik temperatur yang rendah. Pada unit filter PDAM unit Sewon, pH yang dimiliki hanya bernilai 6 hingga 7.2 sedangkan oksidasi mangan akan optimal pada pH tinggi. Selain itu konsentrasi oksigen terlarut juga masih cukup rendah. Kandungan DO tertinggi hanya mencapai 7.09 mg/l, bahkan pada bulan maret kandungan DO hanya 1.22 mg/l. Hal ini menyebabkan removal mangan menjadi kurang optimal.

\section{Kondisi yang Menghambat Efisiensi Proses Pengolahan}

Kondisi yang menghambat atau mengurangi efisiensi proses pengolahan yaitu:

a. $\mathrm{pH}$

Kondisi air pada filter memiliki pH yang bervariasi antara 6.18 - 7.31. Kondisi pH seperti ini merupakan $\mathrm{pH}$ yang cukup untuk oksidasi besi.

b. Oksigen Terlarut

Saat kadar oksigen terlarut dalam sumber air rendah, hal ini dapat menyebabkan kondisi anaerobic pada permukaan media. Untuk oksigen terlarut dibutuhkan $>4 \mathrm{mg} / \mathrm{l}$ agar oksidasi berlangsung efektif.

c. Kecepatan Aliran

Dalam menerapkan prinsip biologis yaitu memanfaatkan kinerja mikroorganisme maka diperlukan kecepatan aliran yang cukup lambat untuk memungkinkan waktu detensi yang lebih 
lama seperti pada slow sand filter. Ketiga unit filter ini memiliki kecepatan aliran $5.6 \mathrm{~m} / \mathrm{jam}$. Kecepatan aliran yang tinggi menyebabkan proses biologi yang terjadi tidak optimal.

d. Media Filter

Media pada filter yaitu berupa pasir. Periode penggantian media yang sangat lama menyebabkan media tidak lagi dalam keadaan fresh (jenuh). Selain itu ukuran butiran dan ketidakseragaman media filter juga berpengaruh pada performance filter.

e. Frekuensi Backwash

Frekuensi backwash yang dilakukan pada PDAM unit Sewon ini adalah setiap hari. Frekuensi backwash yang dilakukan setiap hari menyebabkan lapisan biofilm tidak dapat terbentuk.

\section{Kesimpulan dan Saran}

\section{Kesimpulan}

1. Secara umum kinerja unit filtrasi PDAM unit Sewon dalam menurunkan kadar besi (Fe) cukup baik. Kadar Fe telah memenuhi Baku Mutu Kepmenkes No. 907 Tahun 2002, kecuali pada pengukuran bulan april dan mei yang melebihi $0.3 \mathrm{mg} / \mathrm{l}$. Sedangkan dalam menurunkan kadar mangan, performance unit filter kurang optimal dan tidak memenuhi baku mutu yang ditetapkan. Hal ini disebabkan karena operasional filter tersebut dan faktor kondisi lingkungan yang kurang mendukung.

2. Penggantian sistem backwash dengan menggunakan air baku bertujuan untuk mengoptimalkan kinerja filter dengan memanfaatkan prinsip kerja mikroorganisme. Namun penggantian sistem backwash jika tidak didukung oleh operasional yang benar, kondisi lingkungan, dan juga penggunaan media filter yang tidak seragam, maka menghasilkan kinerja filter yang juga tidak optimal. Hal ini dapat dilihat pada ketiga unit filter yang secara umum menunjukkan kinerja pengolahan yang sama.

\section{Saran}

1. Pemantauan dalam pengoperasian dan pemeliharaan yang teratur merupakan bagian penting dalam menentukan kinerja unit pengolahan air minum.

2. Perlu dilakukan penggantian media filter dilihat dari hasil lengkung ayakan yang menunjukkan bahwa media filter yang digunakan tidak seragam. 
3. Unit filter pada PDAM unit Sewon ini merupakan jenis rapid sand filter sehingga untuk menerapkan prinsip kinerja mikroorganisme akan cukup sulit karena laju filtrasi yang tinggi. Untuk itu laju filtrasi perlu diperlambat antara lain dengan cara mengurangi debit air yang masuk atau mempeluas dimensi filter.

4. Frekuensi sampling sebaiknya ditingkatkan agar dapat diketahui lebih jelas fluktuasi pada unit filter.

\section{Daftar Pustaka}

Boynton,W. R., and W.M. Kemp. (2000). Influence of river flow and nutrient loads on selected ecosystem processes: A synthesis of Chesapeake Bay data. In: J. E. Hobbie (ed.). Estuarine Science: A Synthetic Approach to Research and Practice. Island Press, Washington, D. C.

Departemen Kesehatan RI. Keputusan Menteri Kesehatan RI No. 907/MenKes/SK/VII/2002. Jakarta: Departemen Kesehatan RI, 2002.

OASEO. (2007). Technical Cooperation PDAM Pontianak. OASEN GOUDA, The Netherlands.

R. E. Buchanan. (1996). Studies in The Classification and Nomenclature of The Bacteria. The Bacteriological laboratories, Iowa State College, Ames, Ia. Terdapat pada http://jb.asm.org.

Sawyer, Clair N., Perry L. Mc Carty., Gene F Parkin. (2003). Chemistry for environmental Engineering and science. Mc Graw Hill: New York, USA.

Webber, W.J., Jr., and Stumm, W. (1963). Mechanism of Hydrogen Ion Buffering in Natural Waters. J. Am. Water Works Assoc., 55: 1553. 